Antonio Carreira

\title{
Mi amistad con Antonio Alatorre ${ }^{1}$
}

Me ha parecido oportuno explicar muy brevemente cómo pudo nacer mi amistad con Antonio Alatorre, que era 21 años mayor que yo, y objeto de admiración desde mis tiempos de estudiante. Así se justificará algo mejor que el Fondo de Cultura Económica me haya invitado para participar en su homenaje, cosa que agradezco en el alma a sus dirigentes.

En el año 2000, Alatorre, bajo el epígrafe "De Góngora, Lope y Quevedo", publicó en la Nueva Revista de Filología Hispánica un artículo-reseña cuya primera parte se ocupaba de dos libros míos: una edición crítica de los Romances de Góngora, en cuatro volúmenes, y un conjunto de estudios titulado Gongoremas, ambos impresos dos años antes. Yo era antiguo suscriptor de la revista, y confieso que cuando me puse a leer su trabajo no las tenía todas conmigo. Tantas páginas hablando de mis cosas no me parecían buena señal. Mi sorpresa fue mayúscula al encontrar en el temible Alatorre - temible como crítico y como polemista - concordancias y elogios tan subidos que no podía dar crédito, aunque por medio hubiera pequeñas

\footnotetext{
${ }^{1}$ Conferencia leída en el homenaje póstumo a Antonio Alatorre tributado en la Feria del Libro de Guadalajara (Jalisco) el 28 de noviembre de 2010. Aparecerá con las demás leídas en la misma ocasión en un libro que publicarán próximamente el Fondo de Cultura Económica y El Colegio de México.
} 
disensiones. Se trataba de benevolencia por su parte, desde luego, pero también de algo más: en el fondo, Alatorre acababa de descubrir un alumno español, aunque fuera ya machucho, por las citas de sus trabajos, y por un método filológico que era el suyo. Me produce rubor repetir un párrafo de aquella crítica, pero creo que debo hacerlo, porque pone de relieve su honradez y generosidad:

Es posible que en mi aplauso a Carreira haya influido una razón muy personal. Me siento, en efecto, como identificado con él. Es reconfortante la idea de que avanzamos por el mismo camino y hacemos frente común. Entendemos de manera muy parecida nuestra doble "misión" de investigadores y profesores, aunque yo la cumpla de manera imperfecta, más como aficionado que como profesional. A los dos nos irritan las ediciones hechas a la diabla, con malas notas y mala puntuación del texto. Los dos ponemos muy en alto la edición de las Soledades por Robert Jammes, y también los dos le hacemos uno que otro reparo.

Poco después, me llegó la invitación de El Colegio de México para impartir un curso de doctorado sobre Ecdótica. Pensaba yo que en ello tuviera algo que ver la favorable crítica de Alatorre, pero buenos amigos me aseguraron que no fue así. En cualquier caso, cuando él supo de mi llegada a México, me llamó, nos saludamos, y propusimos una cita para conocernos personalmente. El encuentro tuvo lugar en la sala de reuniones del Centro de Estudios Lingüísticos y Literarios, presidida por un retrato de su maestro, Raimundo Lida. Charlamos, descubrimos amigos comunes, me dio la impresión de que me interrogaba amable pero hábilmente, y no pasamos de ahí. Luego, con la frecuencia del trato, vino el tuteo, me invitó a su casa, le escuché tocar el piano (la música era otra pasión que compartíamos), intercambiamos libros y separatas, nos expusimos 
proyectos, nos pasamos originales, corregimos pruebas juntos, dimos conferencias al alimón. Al regresar yo a España nuestra amistad estaba sólidamente anclada: me llamaba siempre tocayo, y decía, medio en broma, que éramos almas gemelas. Nos escribimos, me pidió ayuda con algún libro raro que necesitaba para su Sor Juana a través de los siglos, más tarde también con algún manuscrito, y yo se la presté, encantado de colaborar con él y de poner a contribución algunos amigos que lo admiraban. Cuando volví a México estaba ya preparando la nueva edición de la Lírica personal de sor Juana, lo invité a hablar del asunto a los doctorandos, aceptó, y yo pude asistir también a alguna de sus clases en la UNAM. De dos libros suyos publiqué largas reseñas que creo que le gustaron, y un día, durante una comida, el actual director general del FCE, Joaquín Díez-Canedo, nos propuso publicar en un volumen las Soledades de Góngora y el Primero Sueño de sor Juana, cosa que no se había hecho antes. Nos pareció una buena idea, y años después el libro, cuidado por Antonio Bolívar, salió a plena satisfacción de todos, mía en especial, ya que me sentí muy honrado al ver mi nombre junto al suyo tan ilustre. La edición ofrece un texto intachable de ambos poemas, con puntuación moderna, y precedido por sendas guías de lectura, a fin de que el lector pueda escucharlos tal como salieron de mano de sus autores, sin aclaraciones que interrumpan su fruición, como si fueran obras musicales, es decir, procurando que la inteligencia colabore con la sensibilidad. Ignoro cuál haya sido el resultado del experimento, pero creo que valía la pena hacerlo: recuperar los dos máximos poemas de España y México en el estado virginal que los conocieron sus primeros lectores. La poesía, como la música, cuando no hay ruidos que la perturben, se defiende por sí sola, está hecha para disfrutar, no para aprender.

Nada más llegar a El Colegio de México por primera vez, pregunté a algún responsable de la $N R F H$ cómo no figuraba retrato de Alatorre en los volúmenes que habían tributado ho- 
menaje a quien era su director desde hacía mucho tiempo; en España sus lectores no conocíamos su aspecto físico, lo que resultaba insólito en la era de la imagen. Me respondieron que así lo había querido él. Cuando por fin lo tuve delante de mí pensé que era fácil de describir: alto, flaco, los ojos saltones y la nariz ganchuda, coincidía con la idea de don Quijote a que nos han acostumbrado los dibujos de Gustave Doré. Y prolongando un poco el símil, no dejan de ser quijotescas las defensas que él hizo, en múltiples trabajos, de dos doncellas desvalidas: una, metafórica, la poesía del Siglo de Oro; otra muy real, sor Juana Inés de la Cruz. La primera, más frágil y etérea que la novela o el teatro, necesitaba paladines como Alatorre, que a la sensibilidad y la lucidez añadía el buen oído. La segunda, porque dio lugar a que algunos malandrines hicieran interpretaciones a su juicio descarriadas. Contra ellas se alza probablemente el título de su entrevista con Miguel de la Vega en 1995: "¿Por qué no dejamos tranquila a sor Juana y nos ponemos a leerla?" Alatorre creía que la gracia y el ingenio de sor Juana están al alcance de cualquiera, aunque sabía de sobra que su lector ideal necesita una cultura nada vulgar. Su amor por sor Juana, a quien de veras descubrió estando en Norteamérica, fue casi un flechazo, pues lo dejó deslumbrado, y a partir de aquel momento le dedicó el tiempo y las energías que le quedaban. Pero tuvo la fortuna de ver impresos la mayoría de sus trabajos, que culminan en la edición de la Lírica personal de sor Juana publicada por el FCE, y tuvo también la satisfacción de saber que su alumna predilecta, Martha Lilia Tenorio, ha recogido la antorcha y puede llevarla muy lejos.

Hay personas cuya valía no se muestra del todo cuando hablan, porque su timidez o cualquier otro factor les hace quedar en la sombra, y se desquitan de aquellas trabas al escribir. Otras, al contrario, brillan en la conversación, pero cuando escriben no dan la misma talla, porque su amenidad es ante todo oral. Alatorre sorprendía por su perfecto equilibrio: escucharlo 
y leerlo eran el mismo fenómeno. En ambos casos asomaba la gracia, y también el tremendo bagaje cultural, mantenido a raya para no caer nunca en la pedantería. En sus palabras destellaban siempre "esos chispazos de inteligencia que son la marca del gran escritor”, según él dijo de su admirado Pedro Mártir de Anghiera. Le gustaba la controversia, el enfrentamiento de pareceres; alguna vez se refirió con ironía al "elegante silencio" que había recibido alguno de sus trabajos más polémicos, como el dedicado al Lazarillo. Las afinidades que según él nos unían eran en realidad enseñanzas suyas y de maestros comunes bien asimiladas, pero nuestra amistad tuvo por base que reconoció en mí un ávido lector, alguien abierto a lo que importa, al margen de modas y oropeles.

No sabría decir cuánto ha perdido México, o qué conciencia tenga el país de lo que ha perdido, con la muerte de Antonio Alatorre, que al fin y al cabo oficialmente solo era un filólogo, especialista en una materia que no quita el sueño a los políticos ni al pueblo llano. Quien conozca su labor de traductor sabe cuánto se le debe por haber vertido ejemplarmente obras de Curtius, Highet, Williams y Béguin, fundamentales para la cultura europea, las de Bataillon y Sarrailh, indispensables para entender la España de los siglos XVI y XVII, y otras de asunto americano igual de importantes como las de Chevalier y Gerbi, publicadas todas ellas por el Fondo de Cultura Económica. Quien quiera iniciarse en su aportación más personal tiene mucho en que escoger, desde Los 1001 años de la lengua española, que reúne multitud de sus saberes, hasta los Fiori di sonetti, deliciosa antología bilingüe de la mejor lírica culta del siglo XVI. Pero a quien solo desee pasar un buen rato aprendiendo a la vez cómo se hace una investigación histórica, se le puede recomendar El brujo de Autlán, libro publicado en 2001 y del que solo hace falta leer la primera mitad, puesto que la segunda es la transcripción de los documentos inquisitoriales que constituyen el proceso del tal brujo a fines del siglo XVII. Con él pagó 
Alatorre una deuda de gratitud hacia su pueblo natal, y de paso, sin pretenderlo, nos dio una lección de cómo la historia, incluso la más seca, puede convertirse en algo vivo, siempre que los legajos caigan en las manos adecuadas. 